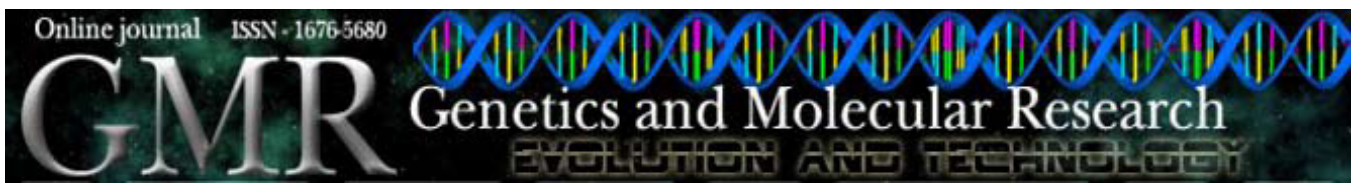

\title{
Non-additive genetic effects on weights and performance of a Brazilian Bos taurus $x$ Bos indicus beef composite
}

G.B. Mourão, J.B.S. Ferraz ${ }^{2}$, J.P. Eler², R.S. Bueno ${ }^{3}$, J.C.C. Balieiro², E.C. Mattos $^{2}$ and L.G.G. Figueiredo ${ }^{4}$

Departamento de Ciências Exatas, Escola Superior de Agricultura "Luiz de Queiroz", Universidade de São Paulo, Piracicaba, SP, Brasil ${ }^{2}$ Departamento de Ciências Básicas, Faculdade de Zootecnia e Engenharia de Alimentos, Universidade de São Paulo, Pirassununga, SP, Brasil

${ }^{3}$ Universidade Tecnológica Federal do Paraná, Dois Vizinhos, PR, Brasil

${ }^{4}$ Departamento de Melhoramento e Nutrição Animal, Faculdade de Medicina Veterinária e Zootecnia,

Universidade Estadual Paulista “Júlio de Mesquita Filho", Botucatu, SP, Brasil

Corresponding author: G.B. Mourão

E-mail: gbmourao@esalq.usp.br

Genet. Mol. Res. 7 (4): 1156-1163 (2008)

Received July 30, 2008

Accepted August 14, 2008

Published October 28, 2008

\begin{abstract}
The aim of the present study was to evaluate the heterosis effects on weaning weight at 205 days (WW, $N=146,464$ ), yearling weight at 390 days ( $\mathrm{YW}, \mathrm{N}=69,315)$ and weight gain from weaning to yearling (WG, $\mathrm{N}=59,307)$ in composite beef cattle. The fixed models were: RM, which included contemporary groups, class of age of dam, outcrossing percentages for direct and maternal effects, and additive direct and maternal (AM) breed effects; R, RM model, minus AM breed effects, and H, RM model, minus additive breed effects. The estimates for W205 were in general positive $(\mathrm{P}<0.01)$. The $\mathrm{R}$ and $\mathrm{H}$ models resulted in similar estimates, but they were very different from the ones estimated by the RM model. For W390, the R and H models resulted in general positive estimates $(\mathrm{P}<0.05)$. For $\mathrm{WG}$, the $\mathrm{RM}$ model resulted in
\end{abstract}


general significant heterosis effects $(\mathrm{P}<0.05)$. It can be concluded that the RM model seems to supply estimates of better quality $(\mathrm{P}<0.01)$.

Key words: Beef cattle; Crossbreeding; Heterosis; Performance

\section{INTRODUCTION}

Nowadays, in search of commercial advantages, cattle producers seem to be more aware of the need to utilize, more intently, enhancement tools, which may optimize gains and efficiency of herds. A natural option is the use of genetic improvement, which enables the identification of bulls with economic traits, thus allowing favorable changes in the current scenario of beef cattle raising.

Besides the direct selection of the best animals, it is also possible to explore the genetic differences existing between breeds through crossbreeding. A good alternative is the composite cattle called Montana Tropical ${ }^{\circledR}$, which has been developed in Brazil since 1994 (Luchiari Filho and Mourão, 2006), aiming to explore, in tropical and sub-tropical climates, the heterosis genetic effects and breed complementarities through the use of bulls for field reproduction in natural copulation.

There are favorable results in the literature, which indicate a heterosis effect on the main domestic species. For weight to weaning of beef cattle, the study of Arthur et al. (1994) reported effects of 19.7 to $24.9 \mathrm{~kg}$ for direct heterosis and 14.9 to $37.8 \mathrm{~kg}$ for maternal heterosis between Hereford and Brahman breeds, generally significant estimates $(\mathrm{P}<0.05)$. Arthur et al. (1999) observed values of 28.0 and $53.5 \mathrm{~kg}(\mathrm{P}<0.01)$ for direct heterosis and $22.5(\mathrm{P}>0.05)$ and $72.6 \mathrm{~kg}(\mathrm{P}<0.01)$ for maternal heterosis between Hereford and Brahman, respectively, in mild and subtropical weather, in a model which includes direct and maternal epistasis, being significant only in subtropical weather.

In Brazil, Perotto et al. (1999), studying the weight of crossbred young males of Red Angus and Nellore breeds, obtained significant values $(\mathrm{P}<0.05)$ for individual and maternal heterosis.

More recently, a literature review by Burrow et al. (2001) found medium heterosis among young bulls of $7.4 \mathrm{~kg}$ (average of 16 studies) and among young bulls $\mathrm{x}$ young zebus ( $\mathrm{T}$ $\mathrm{x} \mathrm{Z}$ ) of $21.7 \mathrm{~kg}$ (average of 10 studies), percent of 3.9 and $12.6 \%$. Average maternal heterosis of $8.2 \mathrm{~kg}$ (3.9\% in 13 studies) among young bulls and $31.1 \% \mathrm{~kg}$ ( $16.0 \%$ in 12 studies) among $\mathrm{T} x \mathrm{Z}$. In the same study the average weight heterosis between the young bulls for the year was $13.2 \mathrm{~kg}$ ( 27 studies), equivalent to $3.8 \%$ of the population average. The referred study does not mention results on composite cattle (young bulls $\mathrm{x}$ young zebus), nor does it refer to the maternal heterosis effect.

Weight traits to weaning (WW), at yearling 390 days (YW) and weight gain from weaning to yearling 390 days (WG) were studied, aiming to determine the contribution of the non-additive genetic effect on beef cattle.

\section{MATERIAL AND METHODS}

\section{Material}

Starting with the herd that originated a crossbred population, characterized by several 
biological traits involved in the formation of a crossbred, information was analyzed regarding WW $(\mathrm{N}=146,464)$, YW $(\mathrm{N}=69,315)$ and $\mathrm{WG}(\mathrm{N}=59,307)$ of calves born between 1994 and 2004, distributed into 2,886, 1,934 and 1,985, respectively, of contemporary groups (CG).

The animals were kept grazing in tropical pastures, the majority in acid soils with $\mathrm{Bra}$ chiaria spp grass. A salt and mineral supplementation was given during all years. Some farms supplement with mineral salt enriched with a protein source in the dry season.

Animals were identified and weighed at weaning and around one year of age. The databank controlled information on performance, breed composition and pedigree of all animals. Animals were grouped into CG that consider the year of birth, farm, management group within farm, and sex.

Breed composition was used to group breeds into biological types N (Bos indicus, zebu cattle), A (Bos taurus, breeds tropically adapted), B (Bos taurus, European cattle of British origin) and $\mathrm{C}$ (Bos taurus, European cattle of continental origin). Further details about the animal management techniques can be found in reports by Ferraz et al. (2002) and Mourão (2005).

Data culling criteria were as follows: a) animals with missing parents or from multiple sires or pastures; b) CG with less than five animals; d) CG with progeny from a single sire; e) $\mathrm{CG}$ with all animals from a single breed composition; f) data from animals with breed composition incompatible with parents, and g) outliers on box-plot by traits (Table 1). The animals with records had 881 sires and 98,288 dams.

Ages of dams at calving were grouped into seven classes, and adjustment factors were considered, such as deviation of least square solutions in relation to class 4 , the class that represents the dam at physiological maturity, defined in accordance with Mourão et al. (2007).

Effects of maternal and direct heterosis were obtained from partial direct heterozygosis among biological types $\mathrm{N}, \mathrm{A}, \mathrm{B}$, and $\mathrm{C}$ and total maternal heterozygosis among the biological maternal types, for example, $\mathrm{N}$ x A = breeding percentage between breeds of biological trait $\mathrm{N}$ and biological trait $\mathrm{A}$ found in the breed formation of the animal. The fractions of direct outcrossing were obtained from the formula, $H_{t y}=\sum\left(p_{i} m_{j}\right)$, where $t$ is the number of biological traits of the system NABC and $p_{i}$ and $m_{j}$ are the contribution fractions to the $\mathrm{i}^{\text {th }}$ and $\mathrm{j}^{\text {th }}$ paternal and maternal biological traits, respectively.

The total maternal outcrossing (MT) was considered as the sum of partial direct outcrossing, as done before; however, being computed as a single total value for the animal's mother.

Estimates for direct and maternal heterosis effects, expressed as outcrossing percentages among $\mathrm{N}, \mathrm{A}, \mathrm{B}$, and $\mathrm{C}$ biological types, were obtained as least square method solutions for linear covariates from analysis of variance, in a procedure similar to that proposed by Dickerson (1973) and used by Mourão et al. (2007).

\section{Statistical analyses}

Based on the maximum likelihood and the genetic model methodologies proposed by Dickerson (1973), three mathematical models, which differ from one another according to the genetic effects, were studied: RM model - complete model, which includes fixed effects of CG, class of age of dam, and the covariates associated with maternal and direct additive genetic effects, and also covariates associated with non-additive genetic effects of outcrossing, for the direct effects as well as for the total maternal effect; R model - RM model minus additive effects of maternal breed, and $\mathrm{H}$ model - $\mathrm{R}$ model minus additive 
breed effects. This last model was used in the process of genetic evaluation of the referred composite.

The likelihood logarithm $\left(\log _{\mathrm{e}} \mathrm{L}\right)$ was used to determine the appropriate models for each trait. The best model for showing expressive influence was considered that showing a significant change in the $\log _{\mathrm{e}} \mathrm{L}$. To determine the most adequate model, the similarity test was applied to the models (Rao, 1973). The statistic of the likelihood rate (LR) was calculated to test the significance of the $i^{\text {th }}$ model, containing additional effects, compared to the other $\mathrm{j}^{\text {th }}$ model, in which these effects were not present. The value was, then, at least twice as high as the natural logarithm of likelihood, that is: $\operatorname{LR}_{\mathrm{ij}}=-2 \log _{\mathrm{e}}\left(\mathrm{L}_{\mathrm{j}} / \mathrm{L}_{\mathrm{i}}\right)=2 \log _{\mathrm{e}}$ $L_{i}-2 \log _{e} L_{j}$, in which $L_{j}$ is the likelihood for model $j$ and $L_{i}$ is the likelihood for model $i$.

The value obtained was then compared with regard to the statistic of the likelihood test (LR) with the chi-squared value $\left(\chi^{2}\right)$ with $\left(l_{i}-1_{j}\right)$ degrees of freedom; the probabilities were determined, and conclusions were made about the significance of the effects included in different models.

\section{RESULTS AND DISCUSSION}

Table 1 shows the natural logarithm values of the likelihood function $\left(\log _{e} L\right)$ for each model in each trait and values of the likelihood rate $\left(\mathrm{LR}_{\mathrm{ii}}\right)$ for pairs of models in each trait studied, obtained through the use of maximum likelihood methodology.

The exclusion of covariates associated with maternal additive genetic effects ( $R$ model) and the exclusion of covariates associated with maternal and direct additive genetic effects (H model), in all traits, led to worse values of $\log _{\mathrm{e}} \mathrm{L}$, when compared to those obtained by the RM model.

Through the test of LR, the RM model demonstrated the best results, significant $(\mathrm{P}<$ 0.05 ) for all traits, showing the importance of including these effects to evaluate these productive traits in crossbred cattle.

\begin{tabular}{|c|c|c|c|}
\hline \multirow[t]{2}{*}{ Model } & \multicolumn{3}{|c|}{$-2 \log _{e} L$} \\
\hline & WW & YW & WG \\
\hline $\mathrm{RM}$ & $1.348 .258,0$ & $647.995,3$ & $515.726,1$ \\
\hline $\mathrm{R}$ & $1.349 .410,0$ & $648.219,9$ & $515.734,5$ \\
\hline \multirow[t]{2}{*}{$\mathrm{H}$} & $1.350 .326,0$ & $648.357,1$ & $515.839,8$ \\
\hline & \multicolumn{3}{|c|}{ Likelihood rate } \\
\hline $\mathrm{LR}_{(\mathrm{RM}-\mathrm{R}) \mathrm{df}=3}$ & 1152.0 & 224.6 & 8.4 \\
\hline $\mathrm{P}<\chi^{2}$ & $<0.0001$ & $<0.0001$ & 0.0384 \\
\hline $\mathrm{LR}_{(\mathrm{RM}-\mathrm{H}) \mathrm{d} \mathrm{f} .=6}$ & 2068.0 & 361.8 & 113.7 \\
\hline $\mathrm{P}<\chi^{2}$ & $<0.0001$ & $<0.0001$ & $<0.0001$ \\
\hline $\mathrm{LR}_{(\mathrm{R}-\mathrm{H}) \mathrm{d} \mathrm{d} . \mathrm{f}=3}$ & 916.0 & 137.2 & 105.3 \\
\hline $\mathrm{P}<\chi^{2}$ & $<0.0001$ & $<0.0001$ & $<0.0001$ \\
\hline
\end{tabular}

d.f. $=$ degrees of freedom. 
The estimates of heterosis effects, obtained from the analysis of variance of models RM, $\mathrm{R}$ and $\mathrm{H}$, related to direct and maternal outcrossing among the biological traits defined through the use of the NABC system, are shown in Table 2, expressed for $100 \%$ of the outcrossing.

For WW all models studied demonstrated positive heterosis effects, which were statistically significant $(\mathrm{P}<0.01)$. Exceptions were $\mathrm{N} x \mathrm{~A}$ heterosis, which was negative $(\mathrm{P}<0.01)$, and $\mathrm{N} x \mathrm{~B}$, which was not significant $(\mathrm{P}=0.83)$, estimated through the $\mathrm{RM}$ model.

\begin{tabular}{|c|c|c|c|c|c|c|c|c|c|}
\hline \multirow[t]{2}{*}{$\mathrm{H}_{\mathrm{ixj}}$} & \multicolumn{3}{|c|}{ Model RM ${ }^{* *}$} & \multicolumn{3}{|c|}{ Model $\mathrm{R}^{* * *}$} & \multicolumn{3}{|c|}{ Model H } \\
\hline & $\beta$ & SE & $\mathrm{P}<|\mathrm{t}|$ & B & SE & $\mathrm{P}<|\mathrm{t}|$ & B & $\mathrm{SE}$ & $\mathrm{P}<|\mathrm{t}|$ \\
\hline \multicolumn{10}{|c|}{ WW (kg) } \\
\hline $\mathrm{N} \times \mathrm{A}$ & -3.97 & 1.25 & 0.0015 & 24.83 & 0.76 & $<0.0001$ & 19.09 & 0.73 & $<0.0001$ \\
\hline $\mathrm{N} \times \mathrm{B}$ & -0.23 & 1.10 & 0.8327 & 7.70 & 0.74 & $<0.0001$ & 19.51 & 0.62 & $<0.0001$ \\
\hline $\mathrm{N} \times \mathrm{C}$ & 7.83 & 2.08 & 0.0002 & 14.81 & 1.82 & $<0.0001$ & 17.06 & 0.72 & $<0.0001$ \\
\hline $\mathrm{A} \times \mathrm{B}$ & 9.78 & 1.02 & $<0.0001$ & 26.30 & 0.76 & $<0.0001$ & 24.84 & 0.70 & $<0.0001$ \\
\hline $\mathrm{A} \times \mathrm{C}$ & 13.15 & 1.96 & $<0.0001$ & 35.49 & 1.81 & $<0.0001$ & 24.20 & 0.80 & $<0.0001$ \\
\hline $\mathrm{B} \times \mathrm{C}$ & 12.66 & 1.94 & $<0.0001$ & 17.68 & 1.93 & $<0.0001$ & 23.46 & 0.98 & $<0.0001$ \\
\hline MT & 4.51 & 0.39 & $<0.0001$ & 3.16 & 0.38 & $<0.0001$ & 3.57 & 0.37 & $<0.0001$ \\
\hline \multicolumn{10}{|l|}{ YW (kg) } \\
\hline $\mathrm{N} \times \mathrm{A}$ & -5.26 & 2.55 & 0.0390 & 21.05 & 1.47 & $<0.0001$ & 15.82 & 1.31 & $<0.0001$ \\
\hline $\mathrm{N} \times \mathrm{B}$ & 11.93 & 2.47 & $<0.0001$ & 25.71 & 1.55 & $<0.0001$ & 30.67 & 1.22 & $<0.0001$ \\
\hline $\mathrm{N} \times \mathrm{C}$ & 2.68 & 4.37 & 0.5400 & 18.62 & 3.63 & $<0.0001$ & 22.84 & 1.43 & $<0.0001$ \\
\hline $\mathrm{A} \times \mathrm{B}$ & 6.45 & 1.59 & $<0.0001$ & 15.88 & 1.17 & $<0.0001$ & 18.00 & 1.11 & $<0.0001$ \\
\hline $\mathrm{A} \times \mathrm{C}$ & -0.64 & 3.65 & 0.8599 & 14.89 & 3.38 & $<0.0001$ & 16.58 & 1.28 & $<0.0001$ \\
\hline $\mathrm{B} \times \mathrm{C}$ & 2.89 & 3.64 & 0.4269 & 8.12 & 3.61 & 0.0245 & 20.17 & 1.66 & $<0.0001$ \\
\hline MT & 1.72 & 0.58 & 0.0033 & 1.01 & 0.58 & 0.0815 & 1.70 & 0.57 & 0.0031 \\
\hline \multicolumn{10}{|l|}{ WG $(\mathrm{kg})$} \\
\hline $\mathrm{N} \times \mathrm{A}$ & -5.86 & 1.93 & 0.0024 & -2.46 & 1.12 & 0.0277 & -3.31 & 1.02 & 0.0011 \\
\hline $\mathrm{N} \times \mathrm{B}$ & 11.98 & 1.89 & $<0.0001$ & 14.76 & 1.21 & $<0.0001$ & 7.27 & 0.95 & $<0.0001$ \\
\hline $\mathrm{N} \times \mathrm{C}$ & 6.66 & 3.41 & 0.0510 & 11.78 & 2.86 & $<0.0001$ & 4.12 & 1.10 & 0.0002 \\
\hline $\mathrm{A} \times \mathrm{B}$ & -0.83 & 1.26 & 0.5089 & -0.57 & 0.93 & 0.5409 & 0.38 & 0.87 & 0.6603 \\
\hline $\mathrm{A} \times \mathrm{C}$ & -1.00 & 2.91 & 0.7312 & -2.18 & 2.69 & 0.4189 & -0.82 & 1.01 & 0.4169 \\
\hline $\mathrm{B} \times \mathrm{C}$ & -0.23 & 2.91 & 0.9379 & -0.83 & 2.87 & 0.7732 & -6.30 & 1.32 & $<0.0001$ \\
\hline MT & -0.37 & 0.46 & 0.4141 & -0.55 & 0.45 & 0.2193 & -0.85 & 0.45 & 0.0569 \\
\hline
\end{tabular}

${ }^{*}$ Estimates expressed for $100 \%$ of outcrossing; $\mathrm{SE}=$ standard error; $\mathrm{H}_{\mathrm{ixj}}$ and MT are direct and maternal outcrossing, respectively, obtained for biological types N, A, B, and C. For example, N x A = percentage of crossbreeding between breeds of biological types $\mathrm{N}$ and A existing in the breed composition of the animal. ${ }^{* *}$ Estimates of maternal and direct additive genetic effects of biological types can be obtained in a report by Mourão et al. (2007).

$\mathrm{R}$ and $\mathrm{H}$ models seem to provide similar estimates per se and different ones in relation to the RM model. It is important to consider the impossibility of discriminating heterosis effects of maternal origin in $\mathrm{R}$ and $\mathrm{H}$ models, due to the fact that maternal biological effect was of great magnitude in this characteristic, as seen.

The direct heterosis effects varied from -3.97 to $13.15 \mathrm{~kg}$, from 7.7 to $26.30 \mathrm{~kg}$ and from 17.06 to $24.84 \mathrm{~kg}$ for RM, R and H models, respectively. When Franke et al. (2001) analyzed the weight from weaning of crossbred Angus, Hereford, Charolais, and Brahman, raised 
in subtropical weather, they found direct heterosis varying from 8.2 to $38.6 \mathrm{~kg}$ and maternal heterosis from -5.3 to $16 \mathrm{~kg}$. These estimates show higher magnitudes than those obtained through the RM model, being closer to the $\mathrm{R}$ and $\mathrm{H}$ estimates and disagreeing with a possible inflation attributed to these models. Perotto et al. (1999), working on data from crossbred Red Angus and Nellore in Brazil, found maternal and individual heterosis effects $(\mathrm{P}<0.001)$ equal to 30.5 and $27.2 \mathrm{~kg}$, respectively.

Still in Brazil, Dal-Farra et al. (2002) estimated for weight gain pre-weaning an effect of $13.2 \mathrm{~kg}$ for maternal heterosis and $14.7 \mathrm{~kg}$ for direct heterosis in crossbred Angus x Nellore and Hereford x Nellore.

For maternal heterosis, the values varied from 3.16 to $4.51 \mathrm{~kg}$ in the different models. These were lower than those obtained by Prayaga (2003), in which direct heterosis among taurine (TT) and zebu (ZZ) and taurine $\mathrm{x}$ zebu (TZ) were $5.8 \mathrm{~kg}$ for ZZ, $11.4 \mathrm{~kg}$ for TZ and 6.2 $\mathrm{kg}$ for TT, and maternal heterosis varied from $1.4 \mathrm{~kg}$ for $\mathrm{ZZ}(\mathrm{P}>0.05)$ to $15.7 \mathrm{~kg}$ for TZ $(\mathrm{P}<$ $0.01)$. Small and very similar magnitudes compared to those found in this study, 5.34 and 2.19 $\mathrm{kg}$ for direct and maternal heterosis, were found by Abdel-Aziz et al. (2003), who worked on crossbreeding of Afrikander and European breeds in South Africa.

Teixeira (2004) estimated important non-additive effects between Hereford and Angus with Nellore, which were 19.6 and $9.6 \mathrm{~kg}$, respectively, for direct heterosis $(\mathrm{P}<0.01)$ and 14.7 and $17.3 \mathrm{~kg}$ for maternal heterosis $(\mathrm{P}<0.01)$.

For yearling weight at 390 days, the $\mathrm{R}$ and $\mathrm{H}$ models estimated positive and significant heterosis effects $(\mathrm{P}<0.05)$, except for $\mathrm{MT}$, in which the effect estimated by the R model was not significant $(P=0.08)$. For $R M$ model, they were significantly important $(P<0.04)$ only for the heterosis effects from outcrossing between $\mathrm{N} x \mathrm{~A}, \mathrm{~N} \times \mathrm{B}, \mathrm{A} \times \mathrm{B}$, and MT, respectively equal to $-0.053,0.119,0.065$ and $0.017 \mathrm{~kg} / \%$.

The $\mathrm{R}$ and $\mathrm{H}$ models, in general, estimate similarities of coefficients based on direction, and discordances based on greater magnitudes through the RM model, as observed for WW and YW.

According to Perotto et al. (1999), in a study conducted in Brazil using Red Angus with Nellore crossbreds, the individual and maternal heterosis effects on yearly weight were of great magnitude $(\mathrm{P}<0.001)$, respectively equal to 55.0 and $19.3 \mathrm{~kg}$. Later, according to Prayaga (2003), direct heterosis among and from young bulls ( $T$ ) and young zebus $(Z)$ were $8.6 \mathrm{~kg}$ (ZZ), $17.9 \mathrm{~kg}$ (TZ; P < 0.01), and $5.7 \mathrm{~kg}$ (TT; P > 0.05); the maternal ones were significant $(\mathrm{P}<0.05)$ equal to $8.7 \mathrm{~kg}(\mathrm{ZZ}), 9.9 \mathrm{~kg}(\mathrm{TZ})$ and $8.4 \mathrm{~kg}(\mathrm{TT})$. These values were very similar to the estimates from the $\mathrm{R}$ and $\mathrm{H}$ models, but higher than those from the RM model found in this study.

Still, according to Teixeira (2004), for post-weaning weight, heterosis between Hereford and Angus with Nellore breeds, were respectively 33.8 and $27.1 \mathrm{~kg}$ for direct heterosis $(\mathrm{P}<0.01)$, again higher than the estimates found in this study. For maternal heterosis, results of $-5.7 \mathrm{~kg}(\mathrm{P}<0.01)$ are contradictory to those found in the current study.

For WG, the RM model estimated significant heterosis effects $(\mathrm{P}<0.05)$ provided by outcrossing among $\mathrm{N} \times \mathrm{A}, \mathrm{N} \times \mathrm{B}$ and $\mathrm{N} \times \mathrm{C}$, respectively equal to $-0.059,0.120$ and 0.067 $\mathrm{kg} / \%$. For the $\mathrm{R}$ model, heterosis effects were significant $(\mathrm{P}<0.05)$ also for outcrossing $\mathrm{N} x \mathrm{~A}$, $\mathrm{N} x \mathrm{~B}$ and $\mathrm{N} x \mathrm{C}$, respectively $-0.025,0.148$ and $0.118 \mathrm{~kg} / \%$. Finally, for the $\mathrm{H}$ model, heterosis effects were significant $(\mathrm{P}<0.05)$, with coefficients equal to $-0.0331,0.0727,0.0412$ and $-0.0630 \mathrm{~kg} / \%$, respectively, for outcrossing $\mathrm{N} \times \mathrm{A}, \mathrm{N} \times \mathrm{B}, \mathrm{N} \times \mathrm{C}$ and $\mathrm{B} \times \mathrm{C}$. Heterosis effects 
from A x B, A x C and MT were not significant $(\mathrm{P}>0.05)$ in any of the models studied.

In Brazil, Perotto et al. (1999), studying Red Angus with Nellore crossbreds, obtained values of 23.3 and $-5.4 \mathrm{~kg}(\mathrm{P}<0.05)$, respectively, for individual and maternal heterosis after the effects had been adapted for weight gain at 185 days. The original estimates were 0.126 and $-0.029 \mathrm{~kg} / \mathrm{day}$.

Although the models provided estimates of heterosis effects relatively similar, in terms of numbers for WG, those derived from RM model showed higher estimates of standard error, which culminated with the absence of statistical significance. This may have occurred due to the great number of GCs and/or to the wide range of observations for this characteristic, along with the increase of parameter numbers in the model.

Using differently expressed data, $\mathrm{kg} / 185$ days instead of $\mathrm{g} /$ day, based on a review of Burrow et al. (2001), average heterosis was found among young bulls (T x T) of $0.6 \mathrm{~kg}$ (19 studies) and among young bulls x young zebus ( $\mathrm{T} \mathrm{x} \mathrm{Z}$ ) of $21.46 \mathrm{~kg}$ ( 6 studies), in percent terms equal to 2.6 and $16.2 \%$ of the parental average. Original estimates were equal to $0.003 \mathrm{~g}$ /day $(\mathrm{T} \times \mathrm{T})$ and $0.116 \mathrm{~g} /$ day $(\mathrm{T} \times \mathrm{Z})$, showing significance $(\mathrm{P}<0.05)$.

Still, Burrow et al. (2001) reported that the maternal heterosis average, weight to weaning, was $8.2 \mathrm{~kg}$ (3.9\% in 13 studies) among $\mathrm{T} \times \mathrm{T}$ and $31.1 \mathrm{~kg}(16.0 \%$ in 12 studies) among $\mathrm{T} \times \mathrm{Z}$. With the same adjustment for gain in 185 days, with results from Prayaga (2003), direct heterosis among and within young bulls (T) and young zebus ( $Z$ ) were $2.7 \mathrm{~kg}(\mathrm{Z}$ x Z), $8.3 \mathrm{~kg}(\mathrm{~T} \times \mathrm{Z})$ and $0.9 \mathrm{~kg}(\mathrm{~T} \times \mathrm{T})$, and maternal heterosis was $3.8 \mathrm{~kg}(\mathrm{Z} \times \mathrm{Z}),-4.8 \mathrm{~kg}(\mathrm{~T} \mathrm{x}$ $\mathrm{Z})$ and $-0.2 \mathrm{~kg}(\mathrm{~T} \times \mathrm{T})$. The original estimates were equal to: $14.5 \mathrm{~g} /$ day $(\mathrm{Z} \times \mathrm{Z}), 44.8 \mathrm{~g} / \mathrm{day}$ ( $\mathrm{T}$ $\mathrm{x} Z$ ), showing significance $(\mathrm{P}<0.05)$, and $4.9 \mathrm{~g} /$ day $(\mathrm{T} \times \mathrm{T} ; \mathrm{P}>0.05)$, and maternal heterosis of $20.4 \mathrm{~g}$ /day $(\mathrm{Z} \times \mathrm{Z})$ and $-25.8 \mathrm{~g}$ /day $(\mathrm{T} \times \mathrm{Z})$ were significant $(\mathrm{P}<0.05)$, and of $-1.2 \mathrm{~g} /$ day $(\mathrm{T}$ $\mathrm{x} T)$ non-significant $(\mathrm{P}>0.05)$.

Teixeira (2004) estimated for weight gain from weaning to post-weaning, non-additive effects between Hereford and Angus with Nellore, which were respectively 25.2 and 15.7 $\mathrm{kg}$ for direct heterosis $(\mathrm{P}<0.01)$, and -6.8 and $-14.8 \mathrm{~kg}$ for maternal heterosis $(\mathrm{P}<0.01)$.

Some of the above mentioned studies report estimates that contradict those found in this study for WG, maybe because of the differences in the calculation mode and evaluation period of weight gain.

Besides, this characteristic shows strong influences from environmental effects, which are difficult to control and/or measure.

As a whole, it is observed that the literature reports estimates similar to those found in this study for weight characteristics at different ages, in spite of the wide range among the studies with regard to models used and results obtained.

\section{CONCLUSIONS}

Estimating models, which are able to segregate and quantify outcrossing effects such as the RM model, should be selected in detriment of those that include singular estimating of heterosis effects, because in these cases the effects are inflated.

Overall, the linear relations between outcrossing and heterosis were important and should be considered in genetic evaluations, since the results support the evidence related to the contribution of genetic heterosis to production systems and animal improvements. Therefore, they can help establish and direct breeding and crossbreeding systems between breeds. 
However, supplementary evaluations are required with more complete models or with other adjustment strategies, and thus, these studies will continue to be of great importance.

\section{ACKNOWLEDGMENTS}

Research supported by FAPESP, CNPq, CAPES, and CFM-Leachman Pecuária Ltda.

\section{REFERENCES}

Abdel-Aziz M, Schoeman SJ and Jordaan GF (2003). Estimation of additive, maternal and non-additive genetic effects of preweaning growth traits in a multibreed beef cattle project. Anim. Sci. J. 74: 169-179.

Arthur PF, Hearnshaw H, Kohun PJ and Barlow R (1994). Evaluation of Bos indicus and Bos taurus straightbreds and crosses. III. Direct and maternal genetic effects on growth traits. Aust. J. Agric. Res. 45: 807-818.

Arthur PF, Hearnshaw H and Stephenson PD (1999). Direct and maternal additive and heterosis effects from crossing Bos indicus and Bos taurus cattle: cow and calf performance in two environments. Livest. Prod. Sci. 57: 231-241.

Burrow HM, Moore SS, Johnston DJ, Barendse W, et al. (2001). Quantitative and molecular genetic influences on properties of beef: a review. Austr. J. Exp. Agric. 41: 893-919.

Dal-Farra RA, Roso VM and Schenkel FS (2002). Environmental effects and heterosis on weight gain from birth to weaning and on visual scores at weaning of beef cattle. Rev. Bras. Zootec. 31: 1350-1361.

Dickerson GE (1973). Inbreeding and Heterosis in Animals. In: Proceedings of the Animal Breeding and Genetics Symposium in Honour of Dr. Lush JL. American Society of Animal Science, Champaign, 54-77.

Ferraz JBS, Eler JP, Dias F and Golden B (2002). Variance Component Estimation for Growth Weights of Montana Tropical, a Brazilian Beef Composite. In: Proceedings of the Genetics Applied to Livestock Production, 7, 2002. WCGALP, Montpellier, 721-724.

Franke DE, Habet O, Tawah LC, Williamns AR, et al. (2001). Direct and maternal genetic effects on birth and weaning traits in multibreed cattle data and predicted performance of breed crosses. J. Anim. Sci. 79: 1713-1722.

Luchiari Filho A and Mourão GB (2006). Melhoramento, Raças e seus Cruzamentos na Pecuária Brasileira. 1ª ed. LinBife, Pirassununga.

Mourão GB (2005). Estimação de efeitos genéticos aditivos diretos e maternos e não aditivos e, predição do desempenho de pesos, perímetro escrotal e musculosidade em uma população de bovinos de corte compostos (Bos taurus $\mathrm{x}$ Bos indicus). $\mathrm{PhD}$ thesis (Animal Science), Faculdade de Zootecnia e Engenharia de Alimentos/Universidade de São Paulo, Pirassununga. Available at [http://www.teses.usp.br/teses/disponiveis/74/74131/tde-17042006-153727/ publico/3628090.pdf]. Accessed February 28, 2007.

Mourão GB, Ferraz JB, Eler JP, Balieiro JC, et al. (2007). Genetic parameters for growth traits of a Brazilian Bos taurus x Bos indicus beef composite. Genet. Mol. Res. 6: 1190-1200.

Perotto D, Abrahão JJS and Cubas AC (1999). Efeitos da raça e da heterozigose sobre características ponderais de bezerros Nelore e mestiços Red Angus x Nelore. Rev. Bras. Zootec. 28: 504-511.

Prayaga KC (2003). Evaluation of beef cattle genotypes and estimation of direct and maternal genetic effects in a tropical environment. 1. Growth traits. Aust. J. Agric. Res. 54: 1013-1025.

Rao CR (1973). Linear Statistical Inference and its Applications. 2nd edn. John Wiley and Sons, New York.

Teixeira RA (2004). Efeitos genéticos aditivos e não aditivos que influenciam características reprodutivas e de crescimento em bovinos de corte. PhD thesis (Animal Science), Faculdade de Ciências Agrárias e Veterinárias, Universidade Estadual Paulista, Jaboticabal. 